\title{
New anti-proliferative agent, MK615, from Japanese apricot "Prunus mume" induces striking autophagy in colon cancer cells in vitro
}

\author{
Shozo Mori, Tokihiko Sawada, Toshie Okada, Tatsushi Ohsawa, Masakazu Adachi, Kubota Keiichi
}

Shozo Mori, Tokihiko Sawada, Toshie Okada, Kubota Keiichi, Second Department of Surgery, Dokkyo University School of Medicine, Kitakobayashi 880, Mibu, Shimotsuga, Tochigi 321-0293, Japan

Tatsushi Ohsawa, Masakazu Adachi, Japan Apricot Co., Ltd., Midori-cho 1-11-7, Takasaki, Gunma 370-0073, Japan

Correspondence to: Tokihiko Sawada, MD, PhD, Second Department of Surgery, Dokkyo University School of Medicine, Kitakobayashi 880, Mibu, Shimotsuga, Tochigi 321-0293,

Japan.tsawada@dokkyomed.ac.jp

Telephone: +81-282-861111 Fax: +81-282-866317

Received: April 9, 2007

Revised: August 27, 2007

\begin{abstract}
AIM: To investigate the anti-neoplastic effects of MK615, an extract from the Japanese apricot (Prunus mume), against colon cancer cells.
\end{abstract}

METHODS: Three colon cancer cell lines, SW480, COLO, and WiDr, were cultured with MK615. Growth inhibition was evaluated by cell proliferation assay and killing activity was determined by lactate dehydrogenase assay. Induction of apoptosis was evaluated by annexin $\mathrm{V}$ flow cytometry. Morphological changes were studied by light and electron microscopy, and immunofluorescence staining with Atg8.

RESULTS: MK615 inhibited growth and lysed SW480, COLO and WiDr cells in a dose-dependent manner. Annexin V flow cytometry showed that MK615 induced apoptosis after $6 \mathrm{~h}$ incubation, at which point the occurrence of apoptotic cells was $68.0 \%, 65.7 \%$ and $64.7 \%$ for SW480, COLO, and WiDr cells, respectively. Light and electron microscopy, and immunofluorescence staining with Atg8 revealed that MK615 induced massive cytoplasmic vacuoles (autophagosomes) in all three cell lines.

CONCLUSION: MK615 has an anti-neoplastic effect against colon cancer cells. The effect may be exerted by induction of apoptosis and autophagy.

(C) 2007 WJG. All rights reserved.

Key words: Colon cancer; Japanese apricot; Prunus mume; Autophagy; Apoptosis; MK615

Mori S, Sawada T, Okada T, Ohsawa T, Adachi M, Keiichi K.
New anti-proliferative agent, MK615, from Japanese apricot "Prunus mume" induces striking autophagy in colon cancer cells in vitro. World J Gastroenterol 2007; 13(48): 6512-6517

http://www.wjgnet.com/1007-9327/13/6512.asp

\section{INTRODUCTION}

Japanese apricot, Prunus mume Sieb. et Zucc. (known as ume in Japanese), has for centuries been a traditional Japanese medicine, and is a familiar and commonly consumed food. Prunus mume is a species of Asian plum of the family Rosaceae. It is often called a plum, but it is more closely related to the apricot (ume in Japanese). MK615, an extract of compounds from Japanese apricot, has been shown to possess an anti-proliferative effect against some cancer cell lines ${ }^{[1,2]}$. Although MK615 induces apoptosis of breast cancer cells and some other human cancer cells, morphological studies have revealed the appearance of abundant cytoplasmic vacuoles early after MK615 exposure, which are not relevant to apoptosis ${ }^{[2]}$. The precise role of these vacuoles has not been elucidated.

Even though effective chemotherapeutic agents and regimens have been developed, colorectal cancer is still associated with high rates of morbidity and mortality worldwide ${ }^{[3,4]}$. Furthermore, the side effects of chemotherapeutic agents often hamper the quality of life of patients with colorectal cancer. There is a need, therefore, to develop new, effective and less toxic chemotherapeutic agents against colorectal cancer.

In the present study, we investigated the antineoplastic effects of MK615 against colon cancer cell lines in vitro. We found that MK615 strongly induced autophagy in colon cancer cells and exerted antineoplastic effects.

\section{MATERIALS AND METHODS}

MK615, derived from the fruit of the Japanese apricot ${ }^{[1]}$, was provided by the Japan Apricot Co. (Gunma, Japan). The preparation involved the extraction of apricot juice using a press. This was then heated and concentrated. The concentrate was dissolved in diethylether, which was then completely removed from the extract by rotary evaporation. The dried hydrophobic extract, MK615, was dissolved in dimethyl sulfoxide (DMSO; Wako Pure Chemical Industry, Osaka, Japan) at several concentrations. 
The MK615/DMSO solution was applied to cell cultures at a concentration of $10 \mu \mathrm{L} / \mathrm{mL}$ of culture medium. DMSO alone was added as a negative control.

\section{Cells}

Three human colon cancer cell lines, SW480, COLO, and WiDr, were purchased from the American Type Culture Collection (Manassas, VA, USA). These three were selected because of the differences in sex, race, and the productivity of proteins, such as carcinoembryonic antigen (CEA). Cells were maintained in Dulbecco's Modified Eagle's Medium (DMEM) containing 10\% fetal calf serum (FCS) in a $5 \% \mathrm{CO}_{2}$ incubator.

\section{Cell proliferation assay}

The cells were plated at $1 \times 10^{4} /$ well in 96-well plates in DMEM containing 10\% (v/v) FCS. The cells were then cultured with or without MK615 at concentrations of 150, 300 or $600 \mu \mathrm{g} / \mathrm{mL}$. For negative control wells, cells were cultured with $1 \%$ DMSO alone. After 48 h, $15 \mu \mathrm{L}$ MTT (3-(4,5-dimethylthiazol-2-yl)-5-(3carboxymethoxyphenyl)2-(4-sulphophenyl)-2H-tetrazolium, inner salt) $(5 \mathrm{~g} / \mathrm{L})$ was added to each well, and the cells were incubated for $4 \mathrm{~h}$. Then, $100 \mu \mathrm{L}$ solubilization solution/stop mix was added following the manufacturer's instructions (Promega, Madison, WI, USA), and the plates were left to stand for $60 \mathrm{~min}$. Absorbances at $570 \mathrm{~nm}$ and $630 \mathrm{~nm}$ were measured with an ELISA reader. Actual counts were calculated by subtracting the absorbance at $570 \mathrm{~nm}$ from that at $630 \mathrm{~nm}$. Each assay was performed in triplicate and the average absorbance was calculated. The data presented here were calculated using the ratio of absorbance at each drug concentration to the absorbance in the absence of drugs.

\section{Lactate dehydrogenase (LDH) assay}

LDH assay was performed using the CytoTox 96 NonRadioactive Cytotoxicity Assay (Promega). Briefly, cells were plated at $5 \times 10^{3} /$ well in 96-well plates in DMEM containing $10 \%(\mathrm{v} / \mathrm{v}) \mathrm{FCS}$, then cultured with or without MK615 at 150, 300 or $600 \mu \mathrm{g} / \mathrm{mL}$. For the negative control wells, cells were cultured with $1 \%$ DMSO alone. The medium was removed and $100 \mu \mathrm{L}$ CytoTox-ONE Reagent was added. Cells were then incubated at $22^{\circ} \mathrm{C}$ for $10 \mathrm{~min}$ and $50 \mu \mathrm{L}$ stop solution added. The plates were shaken for $10 \mathrm{~s}$ and the absorbances at $560 \mathrm{~nm}$ and $590 \mathrm{~nm}$ measured with an ELISA reader. To obtain the maximum $\mathrm{LDH}$ release, $10 \mu \mathrm{L}$ lysis solution $(10 \times)$ was added to the positive control wells $45 \mathrm{~min}$ prior to harvest. After $48 \mathrm{~h}$, a $50 \mu \mathrm{L}$ supernatant was transferred to a fresh 96-well plate, and incubated for $30 \mathrm{~min}$ with $50 \mu \mathrm{L}$ substrate mix at room temperature. Then, $50 \mu \mathrm{L}$ stop solution was added, and the absorbance at $490 \mathrm{~nm}$ measured with an ELISA reader. Each assay was performed in triplicate and the average absorbance calculated. The data presented here were calculated using the formula: percentage cytotoxicity $=100 \times$ (experimental - culture medium background $)$ / (maximum LDH release - culture medium and lysis solution background).

\section{Flow cytometry}

Cells were cultured with MK615 at a concentration of
$300 \mu \mathrm{g} / \mathrm{mL}$ for $6 \mathrm{~h}$, then harvested by trypsinization and washed twice with PBS. Annexin V binding assay was performed using the Annexin V-FITC Apoptosis Detection kit (Becton-Dickinson, NJ) according to the supplier's instructions. At least $1 \times 10^{6}$ cells were incubated with FITC-conjugated annexin $\mathrm{V}$ at room temperature for $15 \mathrm{~min}$. Cells were then analyzed on a FACScalibur flowcytometer (Becton-Dickinson).

\section{Light microscopy}

Cells were cultured with MK615 at a concentration of 300 $\mu \mathrm{g} / \mathrm{mL}$ for $6 \mathrm{~h}$, then collected by trypsinization. Collected cells were mounted on glass slides by the spin-down procedure (50 rpm, $3 \mathrm{~min}$ ) and stained with Diff Quick staining solution (International Reagents, Kobe, Japan). Morphological changes were assessed by light microscopy of Diff Quick specimens.

\section{Electron microscopy}

Cells were cultured with MK615 at concentrations of 150,300 or $600 \mu \mathrm{g} / \mathrm{mL}$ for $6 \mathrm{~h}$, then fixed with $2 \%$ paraformaldehyde $/ 2 \%$ glutaraldehyde in $0.1 \mathrm{~mol} / \mathrm{L}$ phosphate buffer ( $\mathrm{pH}$ 7.4), followed by $1 \%$ osmium tetroxide. After dehydration, thin sections were stained with uranyl acetate and lead citrate for observation using a JEM 100 CX electron microscope (JEOL, Peabody, NY, USA).

\section{Immunofluorescence staining}

Cells were cultured with MK615 at a concentration of $300 \mu \mathrm{g} / \mathrm{mL}$ for $6 \mathrm{~h}$, then fixed in $4 \%$ paraformaldehyde and permeabilized with $0.1 \%$ Triton X-100. They were then washed three times in PBS containing $0.01 \%$ Triton X-100 and 10\% FBS, followed by incubation with antiautophagy cleaved-APG8b (MAPILC3B) antibody (ABGENT, CA, USA), or 4', 6-diamino-2-phenylindole (DAPI) nucleic acid stain (Lonza, Basel, Switzerland).

\section{Statistical analysis}

Statistical analysis for the cell proliferation assay and $\mathrm{LDH}$ assay was performed by Student's $t$ test, comparing the counts at $0 \mu \mathrm{g} / \mathrm{mL}$ MK615 with those at each concentration of MK615. The percentage inhibition was calculated using the ratio of absorbance at each concentration of MK615 relative to the absorbance with no drug added.

\section{RESULTS}

The anti-proliferative effects of MK615 against colon cancer cells were evaluated by cell proliferation assay (Figure 1). The percentage inhibition rates of SW480 at 150,300 and $600 \mu \mathrm{g} / \mathrm{mL}$ MK615 were $31.9 \%, 58.5 \%$ and $54.2 \%$, respectively, and those of COLO and $\mathrm{WiDr}$ were $38.9 \%, 70.4 \%$ and $72.4 \%$, and $12.1 \%, 54.5 \%$ and $58.3 \%$, respectively. The inhibition induced by MK615 at all concentrations was significantly higher than that in the absence of MK615, and was dose-dependent in the COLO and WiDr cell lines.

We examined the ability of MK615 to kill colon cancer cells using a LDH-releasing assay (Figure 2). The percentage specific lysis of SW480 at 0,150, 300 and $600 \mu \mathrm{g} / \mathrm{mL}$ 


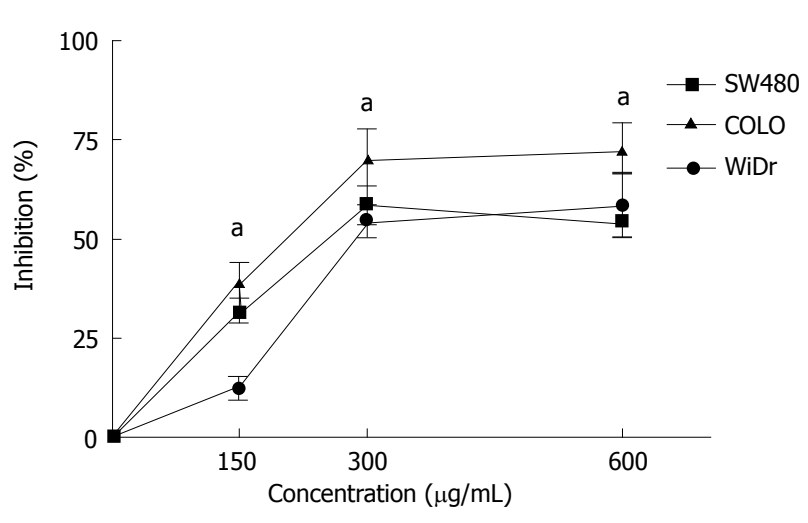

Figure 1 Dose-dependent inhibition of colon cancer cell growth by MK615. Growth inhibition was evaluated by MTT assay. The percentage inhibition ( $\mathrm{Y}$ axis) was calculated using the ratio of absorbance at each drug concentration relative to absorbance in absence of the drugs. ${ }^{a} P<0.05$.

MK615 was $12.5 \%, 11.3 \%, 12.8 \%$ and $49.6 \%$, respectively. The respective values for COLO and WiDr were $21.4 \%$, $33.1 \%, 56.6$ and $58.3 \%$, and $9.4 \%, 6.4 \%, 17.4 \%$ and $50.7 \%$. The percentage specific lysis at all concentrations was significantly higher than that for the controls in all three cell lines.

The antiproliferative effect of MK615 is partly attributed to the induction of apoptosis ${ }^{[2]}$. As shown in Figure 3, MK615 treatment induced apoptosis in all three colon cancer cell lines. After incubation with $300 \mu \mathrm{g} / \mathrm{mL}$ MK615 for $6 \mathrm{~h}$, the frequencies of apoptotic cells in SW480, COLO and WiDr cells were $68.0 \%, 65.7 \%$ and $64.7 \%$, respectively.

It has also been reported that MK615 treatment induces the formation of cytoplasmic vacuoles in breast cancer cells ${ }^{[2]}$. Similarly, in the present study with colon cancer cells, abundant cytoplasmic vacuoles were observed in all three cell lines after $6 \mathrm{~h}$ incubation with MK615 at $300 \mu \mathrm{g} / \mathrm{mL}$ (Figure 4). Electron microscopy revealed that the cytoplasmic vacuoles were typical autophagosomes. Although some cells showed typical features of apoptosis (Figure 5A), there were abundant autophagosomes showing a membrane structure within which cytoplasmic structures were entrapped (Figure $5 \mathrm{~B}-5 \mathrm{~F})$. In some cells, degeneration of mitochondria was observed (Figure 5).

Immunofluorescence staining with Atg8 (LC3) showed positive labeling in all three cell lines after treatment with MK615 (Figure 6). Nuclei were stained blue with DAPI (Figure 6A, 6C and 6E), and Atg8 (LC3) produced peripheral red staining (Figure 6B, 6D and 6F).

\section{DISCUSSION}

In the present study, we showed that MK615 inhibited the growth of three colon cancer cell lines, SW480, COLO, and WiDr, and induced massive autophagy. Apoptosis is a well known form of programmed cell death (PCD), and is widely accepted as the main mechanism of cancer cell death ${ }^{[5-8]}$. Currently, apoptosis is classified as a type I PCD, whereas autophagy is classified as type II $\operatorname{PCD}^{[9-13]}$. Autophagy differs in several ways from type I PCD. Autophagy is a form of caspase-independent cell death,

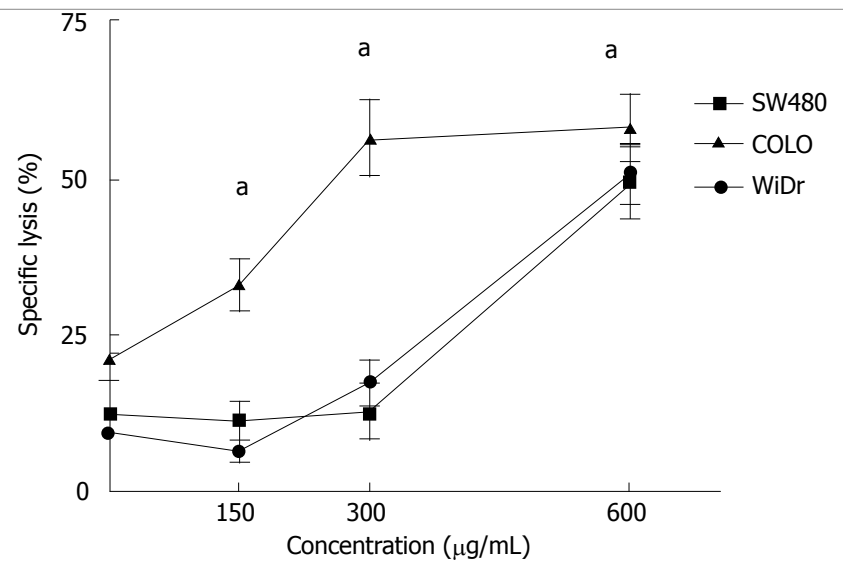

Figure 2 Dose-dependent lysis of colon cancer cells by MK615. Cells were challenged with 150,300 or $600 \mu \mathrm{g} / \mathrm{mL}$ MK615. All three colon cancer cell lines were lysed effectively in a dose-dependent manner. ${ }^{\mathrm{a}} P<0.05$.

displays no DNA-laddering, and is typically characterized by the formation of cytoplasmic vacuoles. In recent years, the importance of autophagy has been stressed in various biological fields, including cancer ${ }^{[14-16]}$. Autophagy is an evolutionarily conserved pathway that delivers and recycles cytoplasmic components, such as mitochondria and Golgi apparatus. Thus, starvation is a typical trigger that can induce autophagy. Some studies have indicated that cancer cells show less autophagy than normal cells ${ }^{[17,18]}$, which suggests that induction of autophagy is an attractive mode of anti-cancer therapy.

Autophagy can be induced by various agents, such as tamoxifen ${ }^{[19]}, \gamma$-irradiation ${ }^{[20,21]}$, and rapamycin ${ }^{[22,23]}$, but few studies have investigated the induction of autophagy by natural substances. A previous study has found that soybean B-group triterpenoid saponins induce macroautophagy in human colon cancer cells ${ }^{[24]}$.

Atg8 is a 117-amino-acid protein essential for the early phase of autophagy ${ }^{[25]}$. LC3 is a mammalian homologue of Atg8 and is the only established marker of autophagy in mammalian cells ${ }^{[2]}$. Conditions such as nutrient starvation initiate the formation of a double-membrane structure, which elongates to form a cytoplasmic vesicle, the autophagosome. Finally, autophagosomes fused with lysosomes generate single-membrane autophagolysosomes, resulting in the degradation of their content. Atg8 (LC3) binds to the membrane of the autophagosome and plays a crucial role in the process of autophagy ${ }^{[27,28]}$. In the present study, MK615 induced the expression of Atg8 (LC3) in all the colon cancer cell lines within 6 h of incubation. Expression of Atg8 (LC3) was exclusively localized in the cytoplasm. These findings indicated that MK615 induced massive autophagy in colon cancer cells in vitro.

Precise elucidation of the mechanism responsible for the antineoplastic effect of MK615 will require further study, as it remains unclear whether autophagy suppresses tumorigenesis or provides cancer cells with a rescue mechanism under unfavorable conditions. Kondo et al have reported that manipulation of autophagy may have different effects in different types of cancer cells. If cancer cells show defective autophagy, induction of autophagy 
A

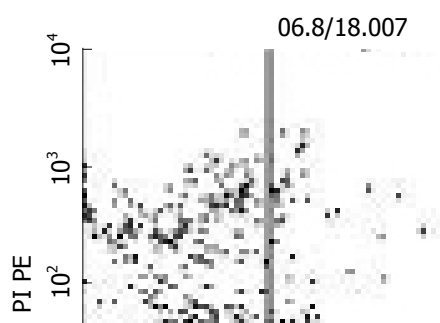

문을

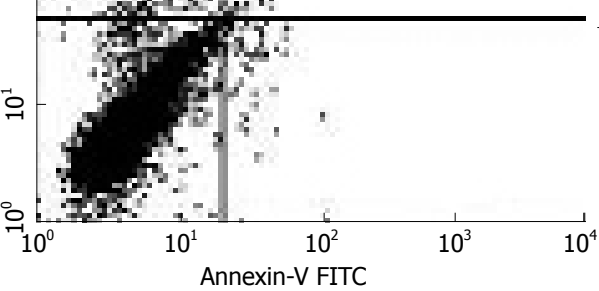

C

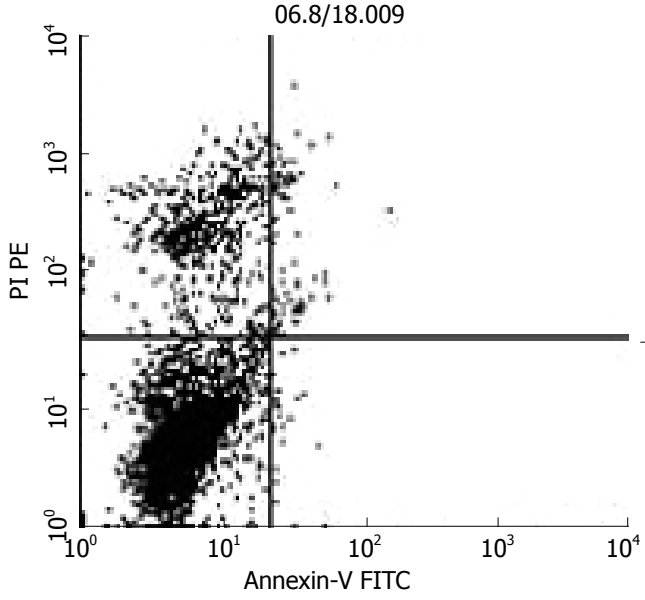

E

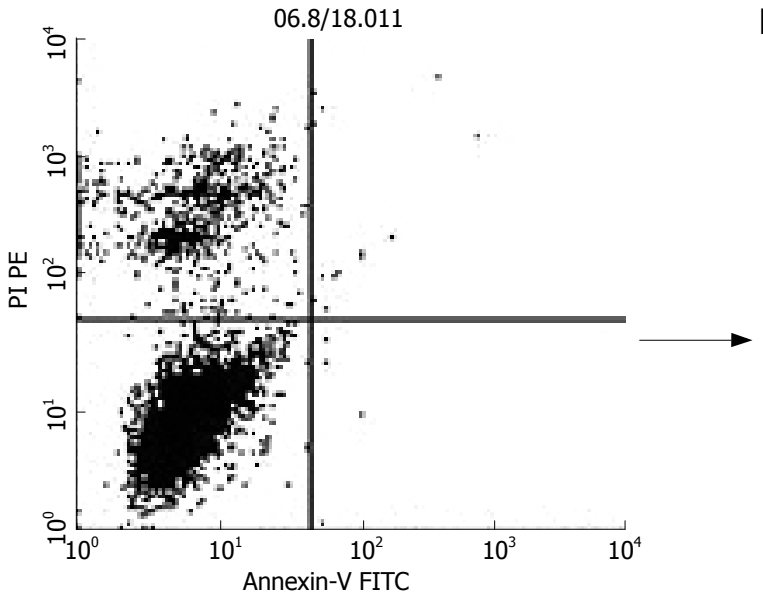

COLO
B

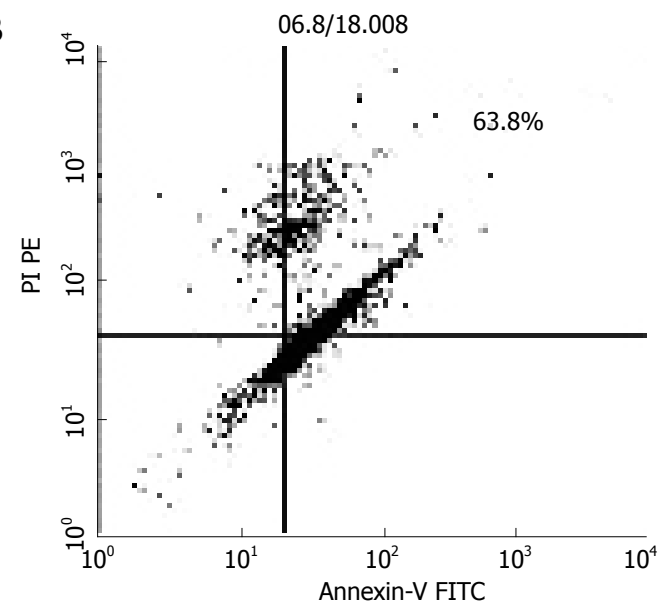

D

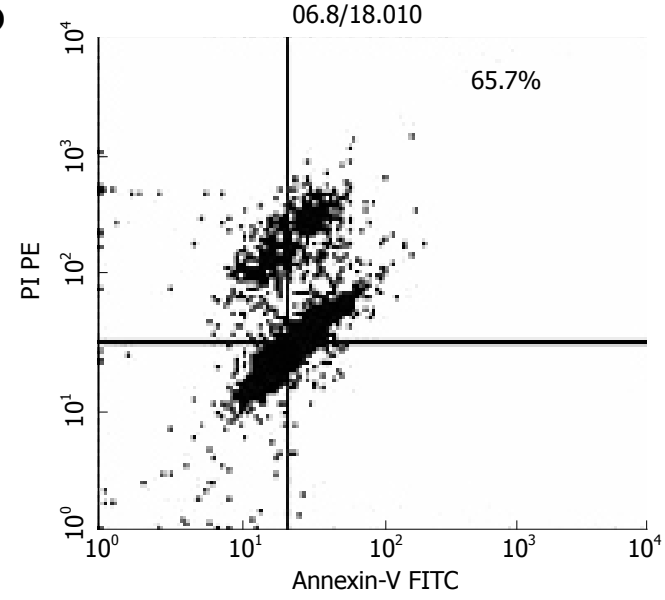

F

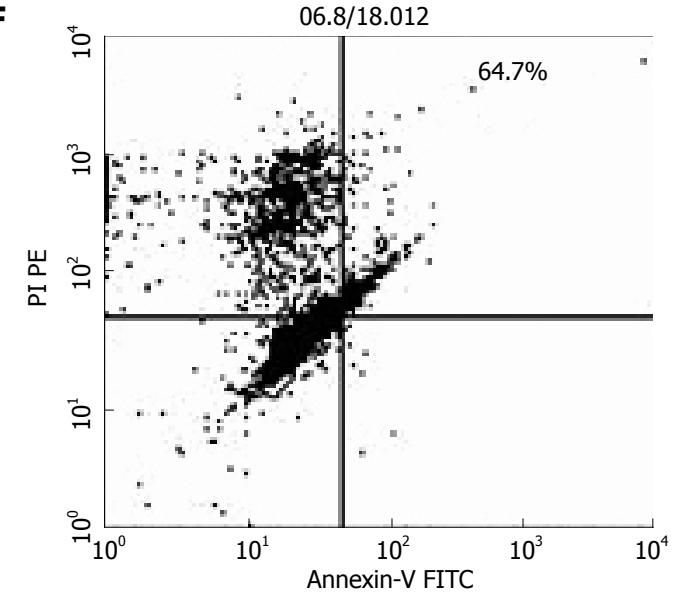

Figure 3 MK615-induced apoptosis in colon cancer cell lines. SW480, COLO and WiDr cells were cultured without (A, C and E) and with (B, D and F) MK615 at $300 \mathrm{~mL}$, and harvested after $6 \mathrm{~h}$ incubation.
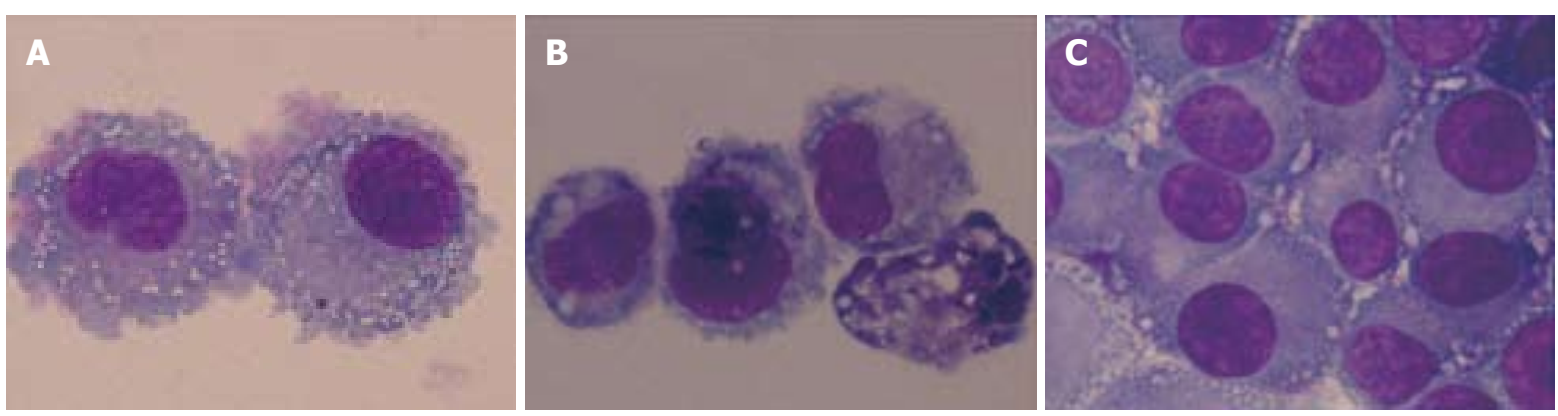

Figure 4 Massive induction of cytoplasmic vacuoles by MK615. MK615 (300 $\mu \mathrm{g} / \mathrm{mL})$ induced cytoplasmic vacuoles in SW480 (A), COLO (B) and WiDr (C) after $6 \mathrm{~h}$ incubation. 


\section{A}
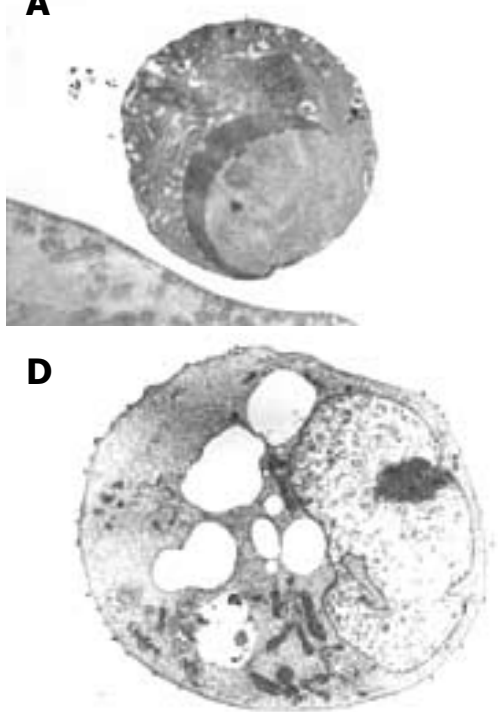

B
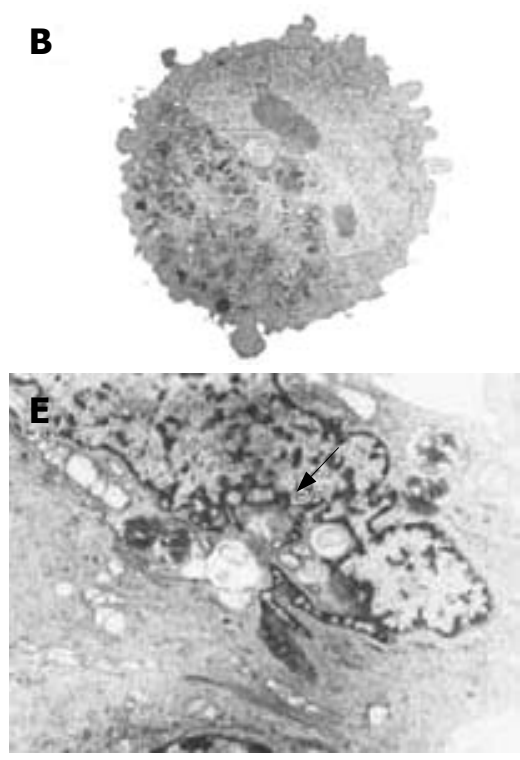

C
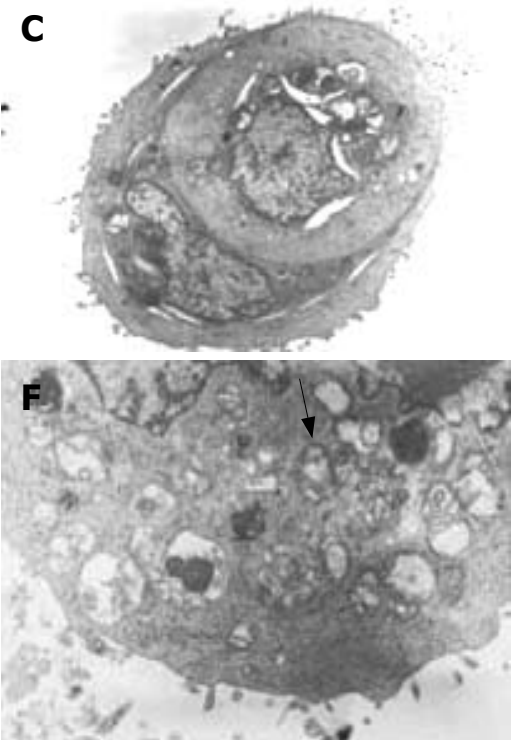

Figure 5 Electron micrographs of autophagy induced by MK615. A: MK615 induced typical features of apoptosis in SW480 cells; B-F: Autophagy induced by MK615. Cytoplasmic vacuoles (autophagosomes) induced by MK615 in SW480 B and C, COLO D and E and WiDr (F) cells. Degenerated mitochondria are evident (arrows in E and F).
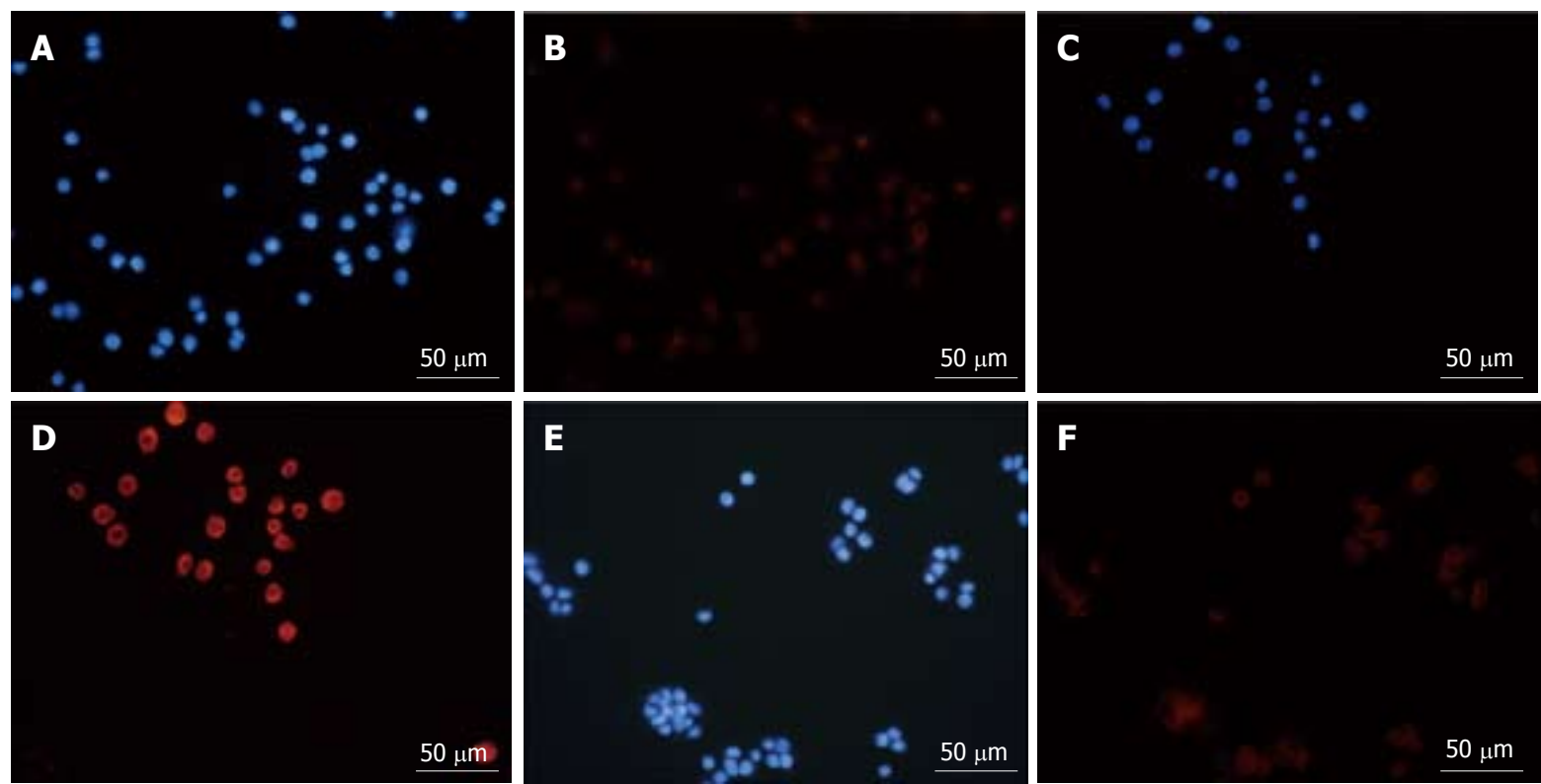

Figure 6 Immunofluorescence staining with Atg8 (LC3). SW480 (A), COLO (B) and WiDr (C) cells were cultured with MK615 at $300 \mu \mathrm{g} / \mathrm{mL}$ for $6 \mathrm{~h}$. Nuclei were stained with $\mathrm{DAPI}(\mathbf{A}, \mathbf{C}$ and $\mathbf{E})$, and Atg8 (LC3) was localized in the cytoplasm (B, D and F; note the central blank area in the cells).

may lead to the inhibition of cancer growth, whereas if cancer cells show protective autophagy in response to chemotherapy, this may decrease their sensitivity to anticancer treatment ${ }^{[29]}$.

Importantly, Boya et al have reported that when cells are inhibited at the final step of autophagy, which is the fusion of autophagosome and lysosome, cells die during type I PCD (apoptosis); on the other hand, when cells complete the whole process of autophagy, they survive. Thus, the inhibition of autophagy causes cells to undergo apoptosis, which suggests that there is cross-talk between type I and type II PCD ${ }^{[30]}$. Indeed, the results of annexin- $V$ flow cytometry indicated that MK615 induced apoptosis after
$6 \mathrm{~h}$ of incubation.

In conclusion, we demonstrated that an extract of compounds from Japanese apricot (ume), MK615, exhibits anti-proliferative effects against colon cancer cells in vitro, and induced massive autophagy in these cells. Although further study is needed, the natural compounds in MK615 appear to exert antineoplastic effects through induction of autophagy-related PCD in colon cancer cells.

\section{ACKNOWLEDGMENTS}

The authors thank Dr. Keiichiro Yamaguchi for his excellent assistance with electron microscopy. 


\section{COMMENTS}

\section{Background}

Japanese apricot, Prunus mume Sieb. et Zucc (ume in Japanese), has for centuries been a traditional Japanese medicine, and is a familiar and commonly consumed food. Some components of Japanese apricot have been shown to inhibit cancer cell growth.

\section{Research frontiers}

MK615 is an extract of compounds from Japanese apricot, and has been shown to possess an anti-proliferative effect against some cancer cell lines. Autophagy is a form of PCD and has been shown to regulate cancer-cell growth. However, there are not many substances that can stably induce autophagy in cancer cells.

\section{Innovations and breakthroughs}

In this report, we clearly described that MK615 inhibited the growth of colon cancer cells by aggressively inducing autophagy.

\section{Applications}

The side effects of chemotherapeutic agents often reduce the quality of life of patients with colorectal cancer. MK615 appears to be an effective and less toxic chemotherapeutic agent against colorectal cancer.

\section{Terminology}

Autophagy is classified as type II PCD, and differs from type I PCD (apoptosis). Autophagy is a form of caspase-independent cell death, displays no DNAladdering, and is typically characterized by formation of cytoplasmic vacuoles. In recent years, the importance of autophagy has been stressed in various biological fields, including cancer.

\section{Peer review}

In this in vitro study, the authors investigated the antineoplastic effects of MK615, an extract from Japanese apricot (ume in Japanese), against colon cancer cells. They concluded that MK615 had an antineoplastic effect against colon cancer cells, and the effect may have been exerted by induction of apoptosis and autophagy.

\section{REFERENCES}

1 Adachi M, Suzuki Y, Mizuta T, Osawa T, Adachi T, Osaka K, Suzuki K, Shiojima K, Arai Y, Masuda K, Uchiyama M, Oyamada T. The Japanese apricot Prunus mume Sieb. et Zucc (Ume) is a rich natural source of novel anti-cancer substance. Int J Food Prop 2007; 10: 375-384

2 Nakagawa A, Sawada T, Okada T, Ohsawa T, Adachi M, Kubota K. New antineoplastic agent, MK615, from UME (a Variety of) Japanese apricot inhibits growth of breast cancer cells in vitro. Breast I 2007; 13: 44-49

3 Terstriep S, Grothey A. First- and second-line therapy of metastatic colorectal cancer. Expert Rev Anticancer Ther 2006; 6: 921-930

4 Monga DK, O'Connell MJ. Surgical adjuvant therapy for colorectal cancer: current approaches and future directions. Ann Surg Oncol 2006; 13: 1021-1034

5 Penn LZ. Apoptosis modulators as cancer therapeutics. Curr Opin Investig Drugs 2001; 2: 684-692

6 Hunter AM, LaCasse EC, Korneluk RG. The inhibitors of apoptosis (IAPs) as cancer targets. Apoptosis 2007; 12: 1543-1568

7 Kabore AF, Johnston JB, Gibson SB. Changes in the apoptotic and survival signaling in cancer cells and their potential therapeutic implications. Curr Cancer Drug Targets 2004; 4: $147-163$

8 Meiler J, Schuler M. Therapeutic targeting of apoptotic pathways in cancer. Curr Drug Targets 2006; 7: 1361-1369

9 Bursch W, Ellinger A, Gerner C, Fröhwein U, SchulteHermann R. Programmed cell death (PCD). Apoptosis, autophagic PCD, or others? Ann N Y Acad Sci 2000; 926: 1-12

10 Bursch W, Hochegger K, Torok L, Marian B, Ellinger A,
Hermann RS. Autophagic and apoptotic types of programmed cell death exhibit different fates of cytoskeletal filaments. J Cell Sci 2000; 113 ( Pt 7): 1189-1198

11 Huang WP, Klionsky DJ. Autophagy in yeast: a review of the molecular machinery. Cell Struct Funct 2002; 27: 409-420

12 Wang CW, Klionsky DJ. The molecular mechanism of autophagy. Mol Med 2003; 9: 65-76

13 Yorimitsu T, Klionsky DJ. Autophagy: molecular machinery for self-eating. Cell Death Differ 2005; 12 Suppl 2: 1542-1552

14 Corcelle E, Nebout M, Bekri S, Gauthier N, Hofman P, Poujeol P, Fénichel P, Mograbi B. Disruption of autophagy at the maturation step by the carcinogen lindane is associated with the sustained mitogen-activated protein kinase/extracellular signal-regulated kinase activity. Cancer Res 2006; 66: 6861-6870

15 Ogier-Denis E, Codogno P. Autophagy: a barrier or an adaptive response to cancer. Biochim Biophys Acta 2003; 1603: 113-128

16 Gozuacik D, Kimchi A. Autophagy as a cell death and tumor suppressor mechanism. Oncogene 2004; 23: 2891-2906

17 Kirkegaard K, Taylor MP, Jackson WT. Cellular autophagy: surrender, avoidance and subversion by microorganisms. Nat Rev Microbiol 2004; 2: 301-314

18 Otsuka $\mathbf{H}$, Moskowitz M. Differences in the rates of protein degradation in untrasformed and transformed cell lines. Exp Cell Res 1978; 112: 127-135

19 Bursch W, Ellinger A, Kienzl H, Török L, Pandey S, Sikorska M, Walker R, Hermann RS. Active cell death induced by the anti-estrogens tamoxifen and ICI 164384 in human mammary carcinoma cells (MCF-7) in culture: the role of autophagy. Carcinogenesis 1996; 17: 1595-1607

20 Yao KC, Komata T, Kondo Y, Kanzawa T, Kondo S, Germano IM. Molecular response of human glioblastoma multiforme cells to ionizing radiation: cell cycle arrest, modulation of the expression of cyclin-dependent kinase inhibitors, and autophagy. J Neurosurg 2003; 98: 378-384

21 Gewirtz DA. Autophagy as a mechanism of radiation sensitization in breast tumor cells. Autophagy 2007; 3: 249-250

22 Takeuchi H, Kanzawa T, Kondo Y, Komata T, Hirohata S, Kyo $\mathrm{S}$, Kondo S. Combination of caspase transfer using the human telomerase reverse transcriptase promoter and conventional therapies for malignant glioma cells. Int J Oncol 2004; 25: 57-63

23 Kim KW, Mutter RW, Cao C, Albert JM, Freeman M, Hallahan $\mathrm{DE}, \mathrm{Lu} \mathrm{B}$. Autophagy for cancer therapy through inhibition of pro-apoptotic proteins and mammalian target of rapamycin signaling. J Biol Chem 2006; 281: 36883-36890

24 Ellington AA, Berhow M, Singletary KW. Induction of macroautophagy in human colon cancer cells by soybean B-group triterpenoid saponins. Carcinogenesis 2005; 26: 159-167

25 Kirisako T, Ichimura Y, Okada H, Kabeya Y, Mizushima N, Yoshimori T, Ohsumi M, Takao T, Noda T, Ohsumi Y. The reversible modification regulates the membrane-binding state of Apg8/Aut7 essential for autophagy and the cytoplasm to vacuole targeting pathway. J Cell Biol 2000; 151: 263-276

26 Yoshimori T. Autophagy: a regulated bulk degradation process inside cells. Biochem Biophys Res Commun 2004; 313: 453-458

27 Ravikumar B, Acevedo-Arozena A, Imarisio S, Berger Z, Vacher C, O'Kane CJ, Brown SD, Rubinsztein DC. Dynein mutations impair autophagic clearance of aggregate-prone proteins. Nat Genet 2005; 37: 771-776

28 Tanida I, Minematsu-Ikeguchi N, Ueno T, Kominami E. Lysosomal turnover, but not a cellular level, of endogenous LC3 is a marker for autophagy. Autophagy 2005; 1: $84-91$

29 Kondo Y, Kanzawa T, Sawaya R, Kondo S. The role of autophagy in cancer development and response to therapy. Nat Rev Cancer 2005; 5: 726-734

30 Boya P, González-Polo RA, Casares N, Perfettini JL, Dessen P, Larochette N, Métivier D, Meley D, Souquere S, Yoshimori T, Pierron G, Codogno P, Kroemer G. Inhibition of macroautophagy triggers apoptosis. Mol Cell Biol 2005; 25: 1025-1040

S- Editor Zhu LH L- Editor Kerr C E- Editor Wang HF 